\title{
Research on the Reasons for the Prosperity of Hanseatic League
}

\author{
Haiyang Jiang \\ School of History \& Culture, Sichuan University, Chengdu, Sichuan, China, 610000
}

Keywords: Reasons, Prosperity, Hanseatic League

\begin{abstract}
There are three reasons for the prosperity of Hanseatic League. The first reason is wonderful natural background The second and most important reason is the social background: the Black Death caused serious productivity problems, the decline in productivity makes the European regions cannot feed themselves, The need for long-distance exchange and trade activities of bulk materials necessary for self-sufficiency must to be solved urgently. This need must be filled by a group or individual and the Hanseatic League coincides with its meeting; third, the organizational structure is fine. The above three reasons together promote the Hanseatic League to flourish.
\end{abstract}

\section{Introduction}

In 1368, the Hanseatic League as a whole, in the war with Denmark to achieve the final victory, forcing the king of Denmark Waldemar IV signed Friede von Stralsund. This news immediately spread to whole Europe. Hanseatic League - a non-state city alliance defeated a sovereign state give Europe a great stimulus. Thus the signing of the 1370 " Friede von Stralsund " marked the culmination of the Hanseatic League. Emperor Charles IV subsequently admitted this at 1375 when he visited Lübeck in public speaking.

The author intends to analyze the reasons for the prosperity of the Hanseatic League from three aspects: the natural background, the social background and the Hanseatic League itself.

\section{The Natural Background}

The Hanseatic League is located in the northern coast of northern Germany, the geographical location and natural conditions are very superior.

The northern part of Germany is located in central Europe, south of Scandinavia, east of the French and Nederland, west of Slavic region, north of Europe inland. Such an excellent geographical location is conducive to the development of transshipment trade in various regions. The types and purchases of the Hanseatic League also illustrate this - they acquired leather, fur, linen, marijuana, rosin and beeswax from Novgorod; bringing fresh fish, wood, fur, dried, iron and copper, pine oil from Scandinavia ; in Western Europe, imported wool, woolen, tin and iron from England, and the wine from France, from the Flanders purchase woolen fabric; in Bruges, Hanseatic League took the lead with the Italian Businessmen, through them to buy shipped spices from the East - this shows that in a certain sense Hanseatic League also participated in the East and West world trade.

In the early Middle Ages inland transportation, due to feudal reasons, land transport facilities are not perfect. The security cannot be guaranteed - robbery may occur anytime and anywhere. The river is natural highway. And the river has some absolute advantages such as low cost, fast, and heavy loads, so the river has been an important player in medieval trade. The northern part of the German has the best river network in Europe, where the river network is intertwined and communicated with the North Sea, the Baltic and Southern Europe. This provides a unique condition for the development of the Hanseatic League. It is these rivers as natural roads that have greatly contributed to the development of the Hanseatic League's long-range trade, thus pushed the Hanseatic League to its apex. 
In the August to October each year there is a large fishing season at Skagerrak Strait, a large number of herring get into the Baltic Sea. At this time people describe "You can use sword to cut the herring." In Europe Middle Ages, the herring is the most important source of protein and meat consumption, and every year the chances of catching herring are concentrated in this 3 months, so the one who control the fishing season could get a huge interest. And natural gives this opportunity to the Hanseatic League which located in the south of the Baltic Sea.

\section{The Social Background}

The crisis of productivity brought by the outbreak of the Black Death is the most critical factor in the prosperity of the Hanseatic League.

At the beginning of the 13th century, the Black Death began to appear in Europe. The first outbreak of the Black Death in the middle of the 14th century showed great power. Professor Russell's detailed statistics on the English 1340-1350 data concluded that the disease resulted in about 20 percent of the population's deaths during this period. The writer who wrote a will in Viterbo on December 31, 1348, was estimated the mortality rate is about 66\% in the Pope's area. The Burgundy region of Givry and the city of Bremen, Hamburg and other cities show that the mortality rate is $40 \%-50 \%$. The European population is in a big recession.

At that time, the level of productivity in overall Europe was low, and good land could yield about 1 to 5-6, while most of the land could only receive 1 to 1.5-2. This shows that enough labor is needed to harvest enough food from the land to feed the Europeans. In the case of a great decline in the labor force, economic pressures were evident in the survivors: the survivors soon realized that they had no enough labor to reproduce when the surplus products before the plague were consumed. How to ensure the survival of survivors has become the most important issue.

Since their own production cannot meet the needs of survivors, where external products, especially raw materials and necessities of life to find? The recent origins which only have small affected by the plague are Scandinavian and Eastern Europe. The Hanseatic League, which has a complete trade network in Scandinavia and Eastern Europe, is undoubtedly the most suitable bearer of material organization and transportation.

In observing the catalog of the Hanseatic League, it is found that most of them are not manufactured but raw materials and necessities, which is more pronounced in the more developed countries. For example, in Denmark, the Hanseatic League exports herring, horses, livestock, cereals, imported linen, beeswax, honey and so on, but still imports woolen, wine and other manufactured goods. This shows that trade is generally at a low level, food and raw materials consisting mainly of the exchange of primary products dominate. This import and export model is not simply to meet the needs of high-end imports and high-end exports products, is not simply export surplus products for their own enough, but the export of their own production for the other's own production. This division of labor is the response of the Europeans in response to the pressure of the death of the Black Death, that is, when they cannot meet their own needs, focus on doing the most advantageous projects in order to exchange for other required product. This division of labor must be based on well-functioning trade, which is good news for the Hanseatic League, which has been operating for many years.

The trade volume is enough to affect of the national economy, but also from another aspect of the division of labor that exists. In 1354 the England through the Hanseatic League wool exports 31651.5 packages of wool a year. The England government has brought 81624.11 pounds of tariff income. This is by no means a small sum, after 200 years the 1551 Henry VIII's total fiscal revenue is 271912 pounds. It can be concluded that at least in England the scale of trade through Hanseatic League is huge. That means the Hanseatic League in fact dominating the royal family.

Hanseatic League monopolized trade in the northern Europe, Bergen: "This business station is also the warehouse, but also the entire raw materials products distribution center of Nordic region." Although there is no clear data that the size of the trade, but it can be very clear that the scale of trade is huge.

In Novgorod, Hanseatic League also monopolized foreign trade. The Hanseatic League reached 
an agreement with Novgorod, and the trade with the third party was to be represented by Novgorod or Hanseatic League, which essentially gave the agent of the entire Slavic region the property to Novgorod. Fur trade is very large, every year from Novgorod to Western Europe, the fur is not less than 500,000. Beeswax is also a very popular product, the candle which Western European countries used in the Middle Ages are almost entirely made of beeswax, according to Novgorod's Tallinn station statistics, the number of beeswax to Western Europe 18.5 tons in 1368. In 1399 1404, at the territory of Hanseatic League, the merchant of the Teutonic Order territory shipped 38 tons of beeswax to Western Europe. The Hanseatic League trade in Novgorod is evident.

In summary, the productivity problems caused by the Black Death, the division of labor in European caused by the productivity problems, the need of exchange caused by the division of labor in European, this need must be filled by a group or individual and the Hanseatic League coincides with its meeting. This is the key reason of Prosperity of Hanseatic League. At this time, the established and well-functioning Hanseatic League has more favorable conditions than all candidates, both in geographical position and in the scope of operation

\section{The Characteristics of the Hanseatic League}

The Hanseatic League is only an extremely loose city coalition, without any modern sense of the sovereign state. This creates the following characteristics - openness, relative closure, nonconformity of goals. I think the most fundamental characteristics is the openness.

Openness is essentially reflected in the Hanseatic League organizational concept on the relatively open attitude and this is the Hanseatic League organization openness deep level performance. The main reason I think is the economic benefits. Hanseatic League is mainly as a commercial organization, so the trade object, of course, the more the better. Open can help increase the number of trading partners. From this point of view, the characteristics of businessmen penetrate into every corner of the organization. Businessmen as the most dynamic groups, they dare to take risks, dare to try to get more profits, and this spirit is necessary for trade in 14th century. At that time, Europe needed an organization to stand out to assume the responsibility of brokers. The brokers had to dare to explore and acquire the necessary materials for production and life for European, and the Hanseatic League, which had the characteristics of businessmen, was just right.

While seeing the openness of the Hanseatic League, it is also important to note its relative closeness. The Hanseatic League protects its in-house trade privileges as much as possible, thereby prohibiting trade with outsiders and even prohibiting marriage with outsiders to protect their own privileges. The trade of the Hanseatic League is based on trade privileges, so it can get the greatest benefit at the lowest cost, and the existence of the Hanseatic privilege gives them a greater advantage than the rival. At any time, monopolies are the best way to get benefits. And this monopoly by the Hanseatic League relatively tightly protected so that in Europe when the need for brokers, only the Hanseatic League itself can do the job.

Hanseatic towns are big or small, their scope of trade are wide or narrow, their trade objectives show a non-consistent characteristics - the existence of different business district of the Hanseatic League proved this point. And this goal of non-consistency just to meet the needs of the European exchange, because not all of the Hanseatic trade partners need long-range large-scale trade, and some only need a small range of exchange, trade is also very small. so the Hanseatic towns can meet the needs of most of the trade partners.

\section{Conclusion}

In short, the Hanseatic League due to their excellent geographical location, 14th century European Social Background and unparalleled organizational structure characteristics, successfully obtained the European Transporter this economic status, from the transshipment trade to obtain a huge fortune, successfully entered the peak of prosperity. 


\section{References}

[1] Cao Lingjun. "On the rise and fall of the Hanseatic League " [A], Changsha: Hunan Normal University Master's thesis, 2001: 3

[2] Thompson. "Medieval Economic and Social History" [M], Shanghai: Commercial Press, 1992

[3] Engels. "The Complete Works of Marne", Vol. 5, "The Debate on Frankfurt," [M], Beijing: People's Publishing House, 1958: 373.

[4] Thompson. "Late European Economic and Social History of the Middle Ages" [M], Shanghai: Commercial Press, 1992

[5] Wu Yu, Qi Shirong. "World History (Ancient History)"[M], Beijing: Higher Education Press, 1994

[6] Song Zhixing, Fan Kang "World Economic History" [M] Volume I, World Economic Publishing House, 1989: 30-31.

[7] "Cambridge European Economic History," Volume IV, "the seventeenth century the continuous expansion of the European economy" [M], World Economic Publishing House, 2003: 5-6

[8] "Cambridge European Economic History," Volume I, "Medieval Agricultural Life" [M], World Economic Publishing House, 2003: 327-328.

[9] Gong Min. "1560 - 1640 British Financial Situation and the Corruption of Nobles and Officials" [J], History Teaching Issues, 2005, (4): 59.

[10] "Cambridge European Economic History" Volume II, "Medieval Trade and Industry" [M], World Economic Publishing House, 2003: 596-597. 